\title{
Reflective Thinking Practice: an Analysis of English Teachers' Perception during Online Learning
}

\author{
Sugita, N.P.A.N. ${ }^{1 *}$, Myartawan, I.P.N. ${ }^{2 *}$, Wahyuni, L.G.E \\ 1,2,3 English Language Ganesha University of Education, Bali, Indonesia
}

\section{A R T I C L E I N F O}

Article history:

Received April 06, 2021

Revised April 09, 2021

Accepted June 24, 2021

Available online August 25, 2021

Kata Kunci:

Berpikir reflektif, pembelajaran

online, keterampilan

Keywords:

Reflective thinking, online learning, skills

DOI:

http://dx.doi.org/10.23887/jpbi.v9i2. 33578

\begin{abstract}
A B S T R A K
Para guru menghadapi tantangan untuk membuat kualitas pembelajaran. Namun guru yang kesulitan dalam merancang pembelajaran online. Penelitian ini bertujuan untuk menganalisis tingkat praktik berpikir reflektif guru bahasa Inggris selama pembelajaran online. Penelitian ini merupakan penelitian deskriptif kualitatif. Subjek penelitian ini adalah tiga orang guru bahasa Inggris. Metode yang digunakan untuk mengumpulkan data yaitu kuesioner, observasi, dan wawancara. Kuesioner self-rated dan pedoman wawancara digunakan sebagai instrumen penelitian ini. Temuan penelitian menunjukkan bahwa guru bahasa Inggris dikategorikan sebagai guru tingkat lanjut, cenderung memanfaatkan empat keterampilan berpikir reflektif terhadap pengajaran mereka, yaitu keterampilan belajar sepanjang hayat, kemampuan menilai diri sendiri, kemampuan percaya diri, dan kemampuan menilai diri sendiri. kesadaran mengajar. Para guru bahasa Inggris merasa bahwa perlu bagi mereka untuk menemukan strategi yang paling efektif untuk mengajar siswa untuk perbaikan masa depan pengajaran mereka. Guru menyadari kekuatan dan kelemahan mereka dalam mengajar, dan percaya bahwa mereka dapat memenuhi kebutuhan mereka sebagai guru dalam meningkatkan kualitas pengajaran mereka. Terakhir, para guru mencoba memikirkan apa yang mereka ajarkan kepada siswa sesuai dengan bidang disiplin mereka sendiri sehingga dapat melakukan proses pembelajaran sesuai dengan kebutuhan siswa.
\end{abstract}

\section{A B S T R A C T}

Teachers face the challenge of creating quality learning. However, teachers have difficulty in designing online learning. This study aims to analyze the level of reflective thinking practice of English teachers during online learning. This research is a qualitative descriptive study. The subjects of this study were three English teachers. The methods used to collect data are questionnaires, observations, and interviews. Self-rated guideline questionnaires and interviews were used as research instruments. The research findings show that English teachers are categorized as advanced teachers and tend to use four reflective thinking skills in their teaching: lifelong learning skills, self-assessment skills, self-confidence skills, and selfassessment skills. They are teaching awareness. The English teachers feel that they must find the most effective strategies to improve their teaching. Teachers are aware of their strengths and weaknesses in teaching and believe that they can meet their needs as teachers in improving the quality of their teaching. Finally, the teachers try what they do to students according to their discipline to carry out the learning process according to the needs of students.

This is an open-access article under the CC BY-SA license. Copyright (C) 2021 by Author. Published by Universitas Pendidikan Ganesha.

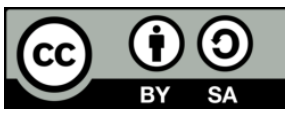

\section{INTRODUCTION}

Doing reflection on the teaching process lets the teachers create the changes to improve their teaching quality and professionalism during teaching the students (Mathew \& Prince, 2017; Sellars, 2012). Reflecting on the teaching conducted before will lead the teachers to understand the outcomes of the learning process (Çepni et al., 2017; Lian et al., 2020). Thus, it allows the teachers to get into the class context where students will learn better, place them in the core of the teaching and learning process, and allow them to enhance the basics of thinking where they can be able to do the decision making correctly (Hatch \& Clark, 2021; Saprudin et al., 2020). When reflective teaching can improve the professionalism among teachers and can positively affect the learning outcomes, the practice of reflection can also improve teachers' perception (Slade et al., 2019; Ratminingsih et al., 2017). The result shows that $94.54 \%$ of teachers believe that the results of reflection they do will affect the improvement of their competencies in planning and conducting the learning process which indirectly means that reflection will also affect the students (Ratminingsih et al., 2017; Töman, 2017). Hence, doing reflection makes it the teachers easier to monitor how far they can enhance their teaching in finding the best solution for different alternative teaching. Since the effect of reflection is giving a big impact on teaching 
and learning practice, doing reflection in their teaching is necessarily needed to be held by teachers during their teaching practice (All et al., 2021; Rodgers, 2010).

As the global outbreak of Covid-19, online learning is applied by most schools in which the teachers are facing the challenges to make the quality of learning process as well as the normal teaching and learning process applied (Goldschmidt, 2020; Mailizar et al., 2020; Mukuka et al., 2021). Here, teachers have a great chance to do the practice of reflection since it can be done flexibly, practically, professionally, and continually (Kim et al., 2020; Lin et al., 2021). For instance in the Buleleng district, where the observation showed that English teachers in some schools were doing the improvement from previous teaching practice as what they believed for better improvement. The reflection they have done fostered certain changes for their teaching. The awareness of doing reflection is important since it can build self-confidence and also great patience in real-world teaching (Lin et al., 2021; Yiwen, 2020). Based on the interview results of some English teachers in SMPS Laboratorium Undiksha, it can be said that English teachers have done the practice of reflection. During online learning, teachers were urged to report the results of their teaching and learning process. The aim was to know whether the online learning was done effectively or not, so the school's stakeholders could evaluate and did such improvements for their teaching practice. The teachers tended to do reflection-on-action, where they reflected before and after conducting teaching practice as the consideration for future learning. During online learning, reflection is done to assess and reflect on themselves as they will use their critical thinking to do the reflective practice (Aufa et al., 2021; Boso et al., 2021).

Reflective teachers are those who own the reflective thinking skills which are divided into four skills i.e. lifelong learning skills, where teachers can assess themselves toward the learning strategies used so they can reflect from it (Kazhikenova et al., 2021; Männikkö \& Husu, 2020). Then, self-assess ability, where teachers can use the previous experiences as the base for improvement to know the strengths and weaknesses of their teaching. Self-belief ability is needed by the teachers to make a good relation with the students so they can teach and understand the needs of students (Brown et al., 2021; Hartmann et al., 2021). Self-belief will give the high motivation for teachers to the best experience in learning for the students. Lastly, reflective teachers are they who can aware of themselves as a teacher for they are owning the skill of teaching awareness (Pen et al., 2020; Yuan \& Mak, 2018). If teachers are having those four skills of reflective thinking, it can be said that teachers are owning the great sense to be reflective teachers. Thus, knowing teachers' perception of reflective thinking is necessary for the improvement of their teaching practice during online learning situations and to create adequate educational fields (Backfisch et al., 2020; Márquez-García et al., 2020).

The teachers who implement the skills of reflective thinking practice in their teaching and learning process, tend to be more responsive to their students' needs (Soisangwarn \& Wongwanich, 2014; Wongwanich et al., 2014). Yet, the teachers who practice the reflective thinking ability will be able to deem their teaching as a learning item, so they can learn from the practice they have done before (Mirzaei et al., 2014; Vassilaki, 2017). Furthermore, by practicing reflective thinking skills, teachers can solve the problems that occurred and get the solutions for them more rather than the teachers who do not have the skills (Finefter-Rosenbluh, 2016; Mirzaei et al., 2014). Besides, by practicing the reflective thinking ability, teachers can also interpret their teaching practice so it can be observed and functioned to foster the teachers' professional teaching and learning practice later on. Since reflective thinking practice is importantly owned by the teachers, each teacher especially EFL teachers needs to know the core concept of reflective thinking practice and how they can realize the reflective practice toward the students (C. Choy \& Oo, 2012).

Thus, this study is necessary to be done to know how the English teachers in SMPS Laboratorium Undiksha perceive themselves as reflective thinking teachers who are facilitating the students with reflective teaching and learning process during the implementation of online learning as it can develop the quality of their teaching. The purpose of this study is to analyze the perception of English teachers during online learning. By knowing the practice of reflection, this study can explain how far the English teachers are utilizing their reflective teaching as one of their professional competence as teachers.

\section{METHOD}

This research belongs to a qualitative descriptive study since the desired phenomenon was directly described by the researcher. To know who, what, and where the phenomenon happened, this kind of research method is utilized Sandelowski, (2000). Regarding English teachers' reflective thinking practice, the qualitative descriptive method was used to let the researcher describe in detail the happening phenomenon, about English teachers' reflective thinking and how they perceive themselves as reflective thinking teachers. This research was conducted in SMPS Laboratorium Undiksha which is located in Buleleng Regency in the academic year of 2020/2021. Since SMPS Laboratorium Undiksha was observed as one school that conduct online learning during the pandemic situation and urge the teachers to evaluate their teaching process for later reporting it to school, doing the practice of reflective thinking was needed to be done by them. Besides, reflection is a necessary action 
to do by teachers since it can be the base for them for further steps of teaching the students. Three English teachers became the subjects of this research to obtain related data about their reflective thinking practice and how they perceive themselves as reflective thinking teachers during online learning in this pandemic of Covid-19 situation.

The self-rated questionnaire and interview guide were used as the instruments for this research. The self-rated questionnaire was used to get data about English teachers' level of reflective thinking based on the four skills of reflective thinking developed by Choy \& Oo, (2012), and adapted by S. C. Choy et al., (2017). The selfrated questionnaire covers four skills as the determiner for teachers' level of reflective thinking, including lifelong learning skill, self-assess ability, self-belief ability, and teaching awareness which were developed into 20 statements. The interview was conducted to get additional information about their real practice of reflection so it can support the findings of the study. The data gathered from the self-rated questionnaire were analyzed quantitatively to get the scores. The results of each teacher were then classified based on the Likert scale (Sugiyono, 2015). The scores showed how the English teachers perceived themselves as reflection practitioners; whether they perceived themselves as introductory or intermediate or advanced reflective thinking teachers. The data were also analyzed qualitatively through discussing each item in the questionnaire which was also supported by the result of the interview, to get a broader analysis of the findings..

\section{RESULT AND DISCUSSION}

\section{Result}

In gathering the data that was previously collected through a self-rated questionnaire, the responses of three English teachers of SMPS Laboratorium Undiksha who are coded as Teacher (T1), Teacher 2 (T2), and Teacher 3 (T3) towards the 20 statements given are explained in this section. Each of the statements contains the skills of reflective thinking practice such as lifelong learning skills, self-assess ability, self-belief, and teaching awareness. This self-rated questionnaire was answered by the English teachers by choosing five options provided. The options were Always (5), Often (4), Sometimes (3), Rare (2), Never (1). Based on data analysis, the English teachers' perceived knowledge of the implementation of their reflective thinking during online learning in SMPS Laboratorium Undiksha. T1 perceived herself as good in the teaching and learning process during online learning with a total score of 72 . Then, T2 got 69 of the total score which means that she perceived herself as good at teaching the students during online learning. Meanwhile, T3 obtained the highest score among the three teachers which was 90. He perceived that he was good at teaching the students in SMPS Laboratorium Undiksha during online learning. In general, it can be inferred that the three English teachers perceived themselves as good enough in reflecting their teaching and learning process to the students with an average score of 77. Based on the Likert scale, it shows that the English teachers in SMPS Laboratorium Undiksha are categorized as advanced teachers in the level of implementing their reflective thinking. This advanced level of reflective thinking implementation was seen in how the English teachers utilized the four skills of reflective thinking such as lifelong learning skills, self-assess ability, self-belief, and also teaching awareness.

Concerning the implementation of lifelong learning skills, the English teachers in SMPS Laboratorium Undiksha perceived that they needed to look for the most effective strategies to teach the students, by considering their characteristics and also the material they taught. In implementing the reflection when teaching, $\mathrm{T} 2$ and $\mathrm{T} 3$ sometimes get inspiration from their colleagues to make innovative ways of teaching, meanwhile, T1 is oftentimes getting inspiration from the colleagues. Therefore, to develop lifelong learning skills, the English teachers also tend to ask certain feedbacks from their students. The teachers reflect on what they presented to the class because they realize that it would influence the way how the students join the lesson given. To sharpen the implementation of their reflective thinking practice, the English teachers frequently integrate their experience toward their current teaching practice for better teaching preparation. They also frequently evaluate their teaching practice to see the effectiveness for the students. Moreover, T1, T2, and T3 were considering what they had done during their lessons so they can improve and discover themselves to apply the knowledge to the students. Therefore, SMPS Laboratorium Undiksha's English teachers reflect their knowledge of reflective thinking in their teaching and learning process in the dimension of lifelong learning skills.

Then, about self-assess ability, the English teachers in SMPS Laboratorium Undiksha apprehended that when they get good comments from students, they think they are doing quite well overall with their teaching practice as teachers. T1 and T2 sometimes think that way and T3 oftentimes considering it. Since pondering others' feedback is strongly connected with self-assess ability, English teachers in SMPS Laboratorium Undiksha are frequently take into consideration the students' feedback given to them as important matters because it will help them to understand the students better and it can be the indicator for the areas of their strengths and weaknesses when conducting teaching and learning process. This action of self-assess ability discloses that the English teachers are less frequently putting aside the feedbacks that come up from their students and they 
assumed that they are more than only giving materials to students, but also implement the realization of reflective practice when teaching during online learning. Likewise in deliberating feedbacks derived from the colleagues, T1 and T3 oftentimes make the assumptions of it and learn from them, sort of different with T2 where she is rare in doing it. Simply, the English teachers made such assumptions toward the feedbacks they got and learned from them. In this way, the English teachers in SMPS Laboratorium Undiksha can be said as owning the skill of self-assess in which they consider what feedback is given by the students to them, yet they also need to contemplate students' comments as a standard for improving their upcoming teaching practice.

Connecting to the skill of self-belief, T1 sometimes believes meanwhile T2 and T3 most frequently believe that they can take care of their needs as teachers such as providing lesson plans, learning media, and also understanding the material that will be taught before transferring the knowledge to students. Reflective teachers are duly to prepare themselves for teaching practice by integrating their past experiences, considering feedbacks given by students, and their colleagues thought of their teaching practice, so they can be responsible to the needs of providing the students such learning materials needed in class. English teachers' self-belief can be seen when they try to look for the connecting areas between what and how they teach with their life experiences. T1 and T2 oftentimes do such practice meanwhile T3 always connecting his life experiences with his teaching practice. By doing this kind of belief, reflective teachers will know the mistakes they made during the implementation of their teaching process can have an impact on their students' lives. Teachers who reflectively thinking tend to have their self-belief and more in mastering their own experiences. Teachers understanding of how they see themselves concerning their students and their ability in teaching the students. In addition to teachers' self-belief, T1 often feels very anxious about students' feedback given to her, as it is obvious that they assess and judge her as a person. T2 is rare in feeling anxious with her students' feedback and so does T3 who never feels anxious with the feedback he receives from his students and so the judgment was given to him.

In the implementation of teaching awareness, the English teachers perceived that to improve their teaching, they try to think about what they teach to the students in terms of their area of discipline. T1, T2, and T3 frequently do such kind of awareness during their teaching practice in online learning. On the contrary, they also have a set of practices that they are comfortable with, although the feedback they received from students and colleagues would help them further enhanced those practices. It indicates that SMPS Laboratorium Undiksha's English teachers are having the awareness in teaching during online learning. Moreover, it is also found that they are aware of their self-quality and the set of their teaching practices will be influenced by their own beliefs. Since having such skills of teaching awareness, the English teachers always try to reflect on what they do during their lessons, so they can enrich the strategies used with new and more effective ones.

\section{Discussion}

Based on the findings of the study, it can be inferred that the English teachers in SMPS Laboratorium Undiksha were categorized as advanced level teachers in implementing reflective thinking practice skills. More specifically, seen from the term of lifelong learning skill, T1, T2, and T3 tend to find the most effective strategies for teaching the students. To make the teachers can face the challenges that occur when teaching the students, they need to prepare or provide themselves with a certain core paradigm and wider understanding of the teaching and learning process, so they are attracted to foster their development in teaching (Aina \& Tuti, 2020; Nurlaily et al., 2019; Pennings et al., 2018). In an aspect of lifelong learning skill, the three English teachers indicate that they perceived themselves as reflective thinking teachers in applying the skill of lifelong learning (Boesdorfer, 2015; Todorescu et al., 2015). In hence, to intensify the lifelong learning skills among teachers, the improvement of metacognitive awareness which is owned by the teachers can be the strategy for them to show their reflective thinking towards the students (Fun \& Maskat, 2010; Schildkamp et al., 2020; Smirnova et al., 2019). They also frequently evaluate their teaching practice to see the effectiveness for the students. Reflective thinking is the process in which one needs to make a careful consideration of certain beliefs that come from the knowledge to support the purpose of the knowledge itself (Rodgers, 2010; Stancescu et al., 2019). Reflective thinking is the cycle of arranging experiences from ones, problems, and also arising insights (Adadan \& Oner, 2018; Mathew \& Prince, 2017). Therefore, SMPS Laboratorium Undiksha's English teachers reflect their knowledge of reflective thinking in their teaching and learning process in the skill of implementing lifelong learning skills.

Regarding self-assess ability, the English teachers in SMPS Laboratorium Undiksha apprehended that when they get good comments from students, they think they are doing quite well overall with their teaching practice as teachers. T1 and T2 were oftentimes considering the students' feedback to make them know better their students and T3 was always considering it which indicates them the good stage of reflective thinking teachers. Thus, in aspect number 11 of self-assess ability, the English teachers in SMPS Laboratorium Undiksha get two (3) and (5) for the score. Besides, the English teachers also make such assumptions of the feedback given by their colleagues ( $\mathrm{T} 1$ got $4, \mathrm{~T} 2$ got 2, and T3 got 4) as a reflection of their reflective thinking practice. The ability of self-assess by teachers is inferred as the ability of teachers to find and assess their strengths and 
weaknesses themselves. Furthermore, teachers can do the self-assess by considering the feedback given from their students and the experiences from teaching and learning they conduct in the classroom (Agustuna et al., 2019; Sata \& Nara, 2017). Here, English teachers are recognizing their strengths and weaknesses in teaching as the way to make them capable to use their previous experiences as the material for future improvement (Noroozi \& Mulder, 2017; Wu et al., 2019). By considering their strengths and weaknesses both in theoretical and practical aspects, teachers will be able to foster their skills in encountering problems that arise during teaching practice (Boesdorfer, 2015; Kaplan, 2018). Reflective thinking skills are needed as the way for educators to enhance the quality of the educational process (Adadan \& Oner, 2018; Mathew \& Prince, 2017). Teachers' colleagues have crucial roles in helping the teachers themselves to think reflectively. Thus, by knowing their strengths and weaknesses as human behavior, teachers will be proficient to reflect on their future improvement. In hence, when English teachers think reflectively and own the skills of reflective practice, they both direct and indirectly assist to create productive and strong qualified individuals for better educational matters (Ambussaidi \& Yang, 2019; Mahmud et al., 2018). Moreover, teachers are also struggling for the development of comprehensive students in which they teach the students to be conscious learners. They hand the students so they can be mindful of the past experiences and filtering them to the future as it is having an improvement (Sutarto et al., 2020).

Teachers need to make connections within the ideas and link them with the upcoming insights before applying them to the practice of their teaching and learning process (Bosica et al., 2021; Stellmacher et al., 2020). Thus, before transferring the knowledge to students, the teachers need to prepare themselves to understand the material as the reflective practice is belonged to the meaning-making process for both students and also teachers (Arfani \& Sulistia, 2019; Torimtubun et al., 2020). Teachers, especially English teachers who think reflectively will be able to develop students with their critical thinking and reflective attitude during online learning (Lan \& Lam, 2020; Margunayasa et al., 2019). Hence, teachers need to consider the factors of set beliefs as it is also shown by previous research that teachers' self-belief is a great factor that will influence teachers themselves in making decisions and planning for their practice of teaching and learning process to students.

Thus, based on the exposures of the four skills of reflective thinking, i.e. lifelong learning skill, selfassess ability, self-belief, and teaching awareness, it can be seen that reflective thinking has important roles in teachers' act as a means of reinforcing them during the process of solving problems since it allows them to take a look back and learn from it to achieve better goals in the future teaching practices (Aina \& Tuti, 2020; Alat \& Dedeoğlu, 2013). During the implementation of online learning, teachers who reflectively thinking by considering the four skills of reflection will themselves be more in tune to use them as strategies to hand their students think critically in the learning process. Thus, in the current situation of online learning, English teachers must own the set of reflective thinking skills to establish effective teaching and learning process for students.

\section{CONCLUSION}

The findings of this study find out that the level of teachers' reflective thinking practice affects how they teach the students in class during online learning, where it means reflective practice among teachers needs to be optimally done to improve the adequacy of educational fields in the future. Based on the results of the findings and discussion of this study, it can be deduced that the English teachers perceived themselves as the advanced level of reflective thinking teachers during online learning. It indicated that in the implementation towards students, the English teachers evaluate their learning process for future improvement so teachers can report their teaching practice to the school and improve themselves.

\section{REFERENCES}

Adadan, E., \& Oner, D. (2018). Examining preservice teachers' reflective thinking skills in the context of webbased portfolios: the role of metacognitive awareness. Australian Journal of Teacher Education, 43(11), 26-50. https://doi.org/10.14221/ajte.2018v43n11.2

Agustuna, N. E., Herlina, R., \& Faridah, D. (2019). Corrective Feedback on Pronunciation Errors: Teacher's Perception and EFL High School Students' Self-Reflection. Journal Of English Education And Teaching, 3(3). https://doi.org/10.33369/jeet.3.3.311-327

Aina, \& Tuti. (2020). Improving Teacher Performance In Classroom Learning Process Through Collaborative Educational Supervisions In Elementary Schools. Primary Jurnal Pendidikan Guru Sekolah Dasar, 9(2). https://doi.org/10.33578/jpfkip.v9i2.7894

Alat, Z., \& Dedeoğlu, N. Ç. (2013). Professional Development of Early Childhood Mentor Teachers in Teaching 
Math. Procedia - Social and Behavioral Sciences, 103(10). https://doi.org/10.1016/j.sbspro.2013.12.244

All, A., Castellar, E. N. P., \& Looy, J. Van. (2021). Digital Game-Based Learning effectiveness assessment:

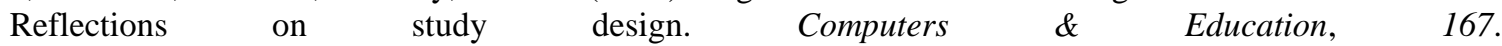
https://doi.org/10.1016/j.compedu.2021.104160

Ambussaidi, I., \& Yang, Y.-F. (2019). The Impact of Mathematics Teacher Quality on Student Achievement in Oman and Taiwan. International Journal of Education and Learning, 1(2), 50-62. https://doi.org/10.31763/ijele.v1i2.39

Arfani, S., \& Sulistia, A. (2019). Teaching Speaking Using A “Snake And Ladder” Board Game: A Teacher Story. Research and Innovation in Language Learning, 2(1). https://doi.org/10.33603/rill.v2i1.1642

Aufa, M. N., Rusmansyah, R., Hasbie, M., Jaidie, A., \& Yunita, A. (2021). The Effect of Using e-module Model Problem Based Learning (PBL) Based on Wetland Environment on Critical Thinking Skills and Environmental Care Attitudes. Jurnal Penelitian Pendidikan IPA, 7(3), 401-407. https://doi.org/10.29303/jppipa.v7i3.732

Backfisch, I., Lachner, A., Hische, C., Loose, F., \& Scheiter, K. (2020). Professional knowledge or motivation? Investigating the role of teachers' expertise on the quality of technology-enhanced lesson plans. Learning and Instruction, 66. https://doi.org/10.1016/j.learninstruc.2019.101300

Boesdorfer, S. B. (2015). Growing Teachers and Improving Chemistry Learning: How Best Practices in Chemistry Teacher Education Can Enhance Chemistry Education. ACS Symposium Series, 1335. https://doi.org/10.1021/bk-2019-1335.ch001

Bosica, J., Pyper, J. S., \& MacGregor, S. (2021). Incorporating problem-based learning in a secondary school mathematics preservice teacher education course. Teaching and Teacher Education, 105. https://doi.org/10.1016/j.tate.2021.103335

Boso, C. M., van der Merwe, A. S., \& Gross, J. (2021). Students' and educators' experiences with instructional activities towards critical thinking skills acquisition in a nursing school. International Journal of Africa Nursing Sciences, 14, 100293. https://doi.org/10.1016/j.ijans.2021.100293

Brown, C., Poortman, C., Gray, H., Ophoff, J. G., \& Wharf, M. M. (2021). Facilitating collaborative reflective inquiry amongst teachers: What do we currently know? International Journal of Educational Research, 105. https://doi.org/10.1016/j.ijer.2020.101695

Çepni, S., Ülger, B. B., \& Ormanci, Ü. (2017). Pre-service science teachers' views towards the process of associating science concepts with everyday life. Journal of Turkish Science Education, 14(4), 1-15. https://doi.org/10.12973/tused.10208

Choy, C., \& Oo, P. S. (2012). Reflective thinking and teaching practices: a precursor for incorporating critical thinking into the classroom? International Journal of Instruction, 5(1), 167-182. https://dergipark.org.tr/tr/pub/eiji/issue/5140/70051

Choy, S. C., Yim, J. S. C., \& Tan, P. L. (2017). Reflective thinking among preservice teachers: a malaysian perspective. Issues in Educational Research, 27(2), 234-251.

Finefter-Rosenbluh, I. (2016). Behind the scenes of reflective practice in professional development: A glance into the ethical predicaments of secondary school teachers. Teaching and Teacher Education, 60. https://doi.org/10.1016/j.tate.2016.07.028

Fun, C. S., \& Maskat, N. (2010). Teacher-Centered Mind Mapping vs Student-Centered Mind Mapping in the Teaching of Accounting at Pre-U Level - An Action Research. International Conference on Learner Diversity, 240. https://doi.org/10.1016/j.sbspro.2010.10.034

Goldschmidt, K. (2020). The COVID-19 Pandemic: Technology use to Support the Wellbeing of Children. Journal of Pediatric Nursing, 53, 88-90. https://doi.org/10.1016/j.pedn.2020.04.013

Hartmann, U., Kindlinger, M., \& Trempler, K. (2021). Integrating information from multiple texts relates to preservice teachers' epistemic products for reflective teaching practice. Teaching and Teacher Education, 97. https://doi.org/10.1016/j.tate.2020.103205

Hatch, L., \& Clark, S. K. (2021). A study of the instructional decisions and lesson planning strategies of highly effective rural elementary school teachers. Teaching and Teacher Education, 108. https://doi.org/10.1016/j.tate.2021.103505

Kaplan, D. E. (2018). Piagetian Theory in Online Teacher Education. Scientific Research Publishing, 9(6). https://doi.org/10.4236/ce.2018.96061

Kazhikenova, G., Zhumataeva, E., Kozhamzharova, M., \& Aubakirova, S. (2021). The effectiveness of reflective dialogue in the development of reflective thinking in rising teachers. Thinking Skills and Creativity, 41. https://doi.org/10.1016/j.tsc.2021.100902

Kim, M., Lee, H., \& Kwak, J. (2020). The changing patterns of China's international standardization in ICT under techno-nationalism: A reflection through 5G standardization. International Journal of Information Management, 54. https://doi.org/10.1016/j.ijinfomgt.2020.102145

Lan, W., \& Lam, R. (2020). Exploring an efl teacher's beliefs and practices in teaching topical debates in 
mainland China. Iranian Journal of Language Teaching Research, 8(1), 25-44. https://doi.org/10.30466/ijltr.2020.120806

Lian, B., Kristiawan, M., Ammelia, D., Primasari, G., Anggung, M., \& Prasetyo, M. (2020). Teachers' Model in Building Students' Character. Journal of Critical Reviews, 7(14), 927-932. https://doi.org/10.31838/jcr.07.14.165

Lin, Y.-N., Hsia, L.-H., \& Hwang, G.-J. (2021). Promoting pre-class guidance and in-class reflection: A SQIRCbased mobile flipped learning approach to promoting students' billiards skills, strategies, motivation and self-efficacyNo Title. Computers \& Education, 160. https://doi.org/10.1016/j.compedu.2020.104035

Mahmud, S. N. D., Nasri, N. M., Samsudin, M. A., \& Halim, L. (2018). Science teacher education in Malaysia: challenges and way forward Siti. Asia-Pacific Science Education ORIGINAL, 4(8), 153-155. https://doi.org/10.1186/s41029-018-0026-3

Mailizar, M., Almanthari, A., Maulina, S., \& Bruce, S. (2020). Secondary School Mathematics Teachers' Views on E-learning Implementation Barriers during the COVID-19 Pandemic: The Case of Indonesia. Eurasia Journal of Mathematics, Science and Technology Education, 16(7), em1860. https://doi.org/10.29333/ejmste/8240

Männikkö, I., \& Husu, J. (2020). Exploring teachers' relational dispositions through reflective noticing. International Journal of Educational Research, 100. https://doi.org/10.1016/j.ijer.2020.101540

Margunayasa, I. G., Dantes, N., Marhaeni, A. A. I. N., \& Suastra, I. W. (2019). The Effect of Guided Inquiry Learning and Cognitive Style on Science Learning Achievement. International Journal of Instruction, 12(1), 737-750. https://doi.org/10.29333/iji.2019.12147a

Márquez-García, M. J., Kirsch, W., \& Leite-Mendez, A. (2020). Learning and collaboration in pre-service teacher education: Narrative analysis in a service learning experience at Andalusian public schools. Teaching and Teacher Education, 96. https://doi.org/10.1016/j.tate.2020.103187

Mathew, P., \& Prince, J. P. (2017). Reflective practices: a means to teacher development. Language and Language Teaching Journal, 15(1), 126-131. https://doi.org/10.24071/11t.2012.150102

Mirzaei, F., Phang, F. A., \& Kashefi, H. (2014). Measuring Teachers Reflective Thinking Skills. Procedia Social and Behavioral Sciences, 141. https://doi.org/10.1016/j.sbspro.2014.05.112

Mukuka, A., Shumba, O., \& Mulenga, H. M. (2021). Students' experiences with remote learning during the COVID-19 school closure: implications for mathematics education. Heliyon, 7(7). https://doi.org/10.1016/j.heliyon.2021.e07523

Noroozi, O., \& Mulder, M. (2017). Design and Evaluation of a Digital Module with Guided Peer Feedback for Student Learning Biotechnology and Molecular LifeSciences, Attitudinal Change, and Satisfaction. Biochemistry and Molecular Biology Education, 45(1), 31-39. https://doi.org/10.1002/bmb.20981

Nurlaily, V. A., Soegiyanto, H., \& Usodo, B. (2019). Elementary school teacher's obstacles in the implementation of problem-based learning model in mathematics learning. Journal on Mathematics Education, 10(2), 229-238. https://doi.org/10.22342/jme.10.2.5386.229-238

Pen, T. T.-L., Marchand, C., Léocadie, M., \& Rothan-Tondeur, M. (2020). Reflective writing: Implementation and learning perception from students and teachers of French nursing schools. Nurse Education in Practice, 49. https://doi.org/10.1016/j.nepr.2020.102921

Pennings, H. J. M., Brekelmans, M., Sadler, P., Claessens, L. C. A., van der Want, A. C., \& van Tartwijk, J. (2018). Interpersonal adaptation in teacher-student interaction. Learning and Instruction, 55, 41-57. https://doi.org/10.1016/j.learninstruc.2017.09.005

Ratminingsih, N. ., Artini, L. ., \& Padmadewi, N. . (2017). Incorporating self and peer assessment in reflective teaching practices. International Journal of Instruction, 10(04), 165-184. https://doi.org/10.12973/iji.2017.10410a

Rodgers, C. (2010). Defining Reflection: Another Look at Jhon Dewey and Reflective Thinking. Teachers College Record, 104(4), 842-866. https://doi.org/10.1111/1467-9620.00181

Sandelowski, M. (2000). Whatever happened to qualitative description? Research in Nursing Health, 23(04), 334-340.

Saprudin, S., Liliasari, L., Setiawan, A., \& Prihatmanto, A. (2020). Optical Gamification (OG); Serial Versus Random Model to Improve Pre-Service Physics Teachers' Concept Mastery. International Journal of Emerging Technologies in Learning (IJET), 15(9), 39-59. https://doi.org/10.3991/ijet.v15i09.11779

Sata, T., \& Nara, Y. (2017). Feedback of the knowledge obtained through the analysis of learning needs for risk literacy education. Procedia Computer Science, 112. https://doi.org/10.1016/j.procs.2017.08.223

Schildkamp, K., Kleij, van der, Heitink, Kippers, W. B., \& Veldkamp, B. P. (2020). Formative assessment: A systematic review of critical teacher prerequisites for classroom practice. International Journal of Educational Research. https://doi.org/10.1016/j.ijer.2020.101602

Sellars, M. (2012). Teachers and change: the role of reflective practice. Procedia - Social and Behavioral 
Sciences, 55, 461-469. https://doi.org/10.1016/j.sbspro.2012.09.525

Slade, M. ., Burnham, T. ., Catalana, S. ., \& Waters, T. (2019). The impact of reflective practice on teacher candidates' learning. International Journal for the Scholarship of Teaching and Learning, 13(02), 1-8. https://doi.org/10.20429/ijsotl.2019.130215

Smirnova, Vaganova, Lebedeva, Livshits, \& Kaznacheeva. (2019). Management of Teacher Certification in Educational Institution. International Journal of Innovative Technology and Exploring Engineering, 9(2), 1038-1042. https://doi.org/10.35940/ijitee.k2131.129219

Soisangwarn, A., \& Wongwanich, S. (2014). Promoting the Reflective Teacher through Peer Coaching to Improve Teaching Skills. Procedia - Social and Behavioral Sciences, 116. https://doi.org/10.1016/j.sbspro.2014.01.601

Stancescu, I., Draghicescu, L. M., Petrescu, A.-M. A., \& Gorghiu, G. (2019). Reflective Practice in the Context of Teachers` Continuous Professional Development. Pro Edu. International Journal of Educational Sciences, 1(1), 5-14. https://doi.org/10.26520/peijes.2019.1.1.5-14

Stellmacher, A., Ohlemann, S., Pfetsch, J., \& Ittel, A. (2020). Pre-service teacher career choice motivation: A comparison of vocational education and training teachers and comprehensive school teachers in Germany. International Journal for Research in Vocational Education and Training, 7(2), 214-236. https://doi.org/10.13152/IJRVET.7.2.5

Sugiyono. (2012). Metode Penelitian Kuantitatif, Kualitatif, dan R\&D. Alfabeta.

Sutarto, S., Sari, D. P., \& Fathurrochman, I. (2020). Teacher Strategies in Online Learning to Increase Students ' Interest in Learning During COVID-19 Pandemic. Jurnal Konseling Dan Pendidikan, 8(3), 129-137. https://doi.org/10.29210/147800

Todorescu, L., Popescu-mitroi, M., \& Greculescu, A. (2015). Students 'Views on the Teacher as An Information Provider Students ' Views on the Teacher as An Information Provider. Procedia - Social and Behavioral Sciences, 197(November), 184-189. https://doi.org/10.1016/j.sbspro.2015.07.121

Töman, U. (2017). Investigation to improve the process of pre-service teachers' reflective thinking skills through an action research. Universal Journal of Educational Research, 5(9), 1535-1548. https://doi.org/10.13189/ujer.2017.050911

Torimtubun, H., Arifin, S., \& Yarnest. (2020). Analysis of the Influence of Character, Compensation and Teaching Experience on Teacher Professionalism in the Kepulauan Tanimbar Regency of Indonesia. International Journal of Advances in Scientific Research and Engineering, 06(08), 74-81. https://doi.org/10.31695/ijasre.2020.33863

Vassilaki, E. (2017). Reflective writing, reflecting on identities: The construction of writer identity in student teachers' reflections. Linguistics and Education, 42. https://doi.org/10.1016/j.linged.2017.08.001

Wongwanich, S., Sakolrak, S., \& Piromsombat, C. (2014). Needs for Thai Teachers to Become a Reflective Teacher: Mixed Methods Needs Assessment Research. Procedia - Social and Behavioral Sciences, 116. https://doi.org/10.1016/j.sbspro.2014.01.450

Wu, W. H., Kao, H. Y., Wu, S. H., \& Wei, C. W. (2019). Development and evaluation of affective domain using student's feedback in entrepreneurial Massive Open Online Courses. Frontiers in Psychology, 10(MAY). https://doi.org/10.3389/fpsyg.2019.01109

Yiwen, Z. (2020). How do we understand mathematical practices in non-mathematical fields? Reflections inspired by cases from 12th and 13th century China. Historia Mathematica, 52. https://doi.org/10.1016/j.hm.2020.04.004

Yuan, R., \& Mak, P. (2018). Reflective learning and identity construction in practice, discourse and activity: Experiences of pre-service language teachers in Hong Kong. Teaching and Teacher Education, 74. https://doi.org/10.1016/j.tate.2018.05.009 